\title{
IMPLEMENTASI MANAJEMEN KUALITAS DAN FAKTOR-FAKTOR YANG MEMPENGARUHI KEPUASAN PELANGGAN PDAM LOMBOK TENGAH
}

\author{
L. WIRAHMAN $W^{1)}$, I GEDE PUTU WARKA ${ }^{2)}$, I.A.O SUWATI SIDEMAN ${ }^{3)}$ \\ Fakultas Teknik Universitas Mataram \\ e-mail :gdputuwarka@gmail.com
}

\begin{abstract}
ABSTRAK
Air minum adalah salah satu kebutuhan pokok yang harus dipenuhi baik kualitas maupun kuantitas. PDAM Lombok Tengah adalah perusahaan daerah yang bergerak dalam bidang pelayanan pada masyarakat dalam bidang air minum yang melayani 12 kecamatan daerah pelayanan. Kota Praya merupakan wilayah pelayanan yang perlu mendapatkan perhatian utama mengingat wilayah ini memberikan andil keuntungan terbesar dengan jumlah pelanggan mencapai $71,83 \%$ dari keseluruhan pelanggan. Adanya keluhan-keluhan para pelanggan terhadap pelayanan yang diberikan oleh PDAM Lombok Tengah megindikasikan belum optimalnya pelayanan yang diberikan oleh PDAM Lombok Tengah. PDAM Lombok Tengah harus mampu mencermati kondisi dan fenomena-fenomena di masyarakat yang menyangkut faktor-faktor yang mempengaruhi kepuasan pelanggan-pelanggannya, untuk kemudian direspon dengan implememntasi manajemen kualitas yang memadai.

Berdasarkan penelitian yang telah dilakukan dapat di ketahui bahwa Rata -rata skor penilaian tingkat impelmentasi manejemen kuailitas tertinggi adalah 75,88\%, yang berkaitan dengan berkaitan dengan menggunakan dan mengkomunikasikan imformasi pelanggan. Tingkat kepuasan pelanggan rumah tangga PDAM kota praya Lombok Tengah berada pada ktegori cukup puas yang ditunjukkan dengan skor tingkat kepuasan rata -rata 64,167\%. Adapun Tingkat kepuasan pelanggan rumah tanggan PDAM Lombok tengah untuk wilayah praya sebagian besar di pengaruhi oleh kulitas air,kontinuinitas air,tekanan air, kondisi meter air, perbaikan dan pemeliharaan, system penagihan dan pembayaran, tarif air,dan kualitas air.
\end{abstract}

Kata kunci: Manajemen kualitas, Pelanggan, Tingkat Kepuasan, Implementasi.

\section{ABSTRACT}

Drinking water is one of human's primary needs that must be fulfilled in term of quantity and quality. PDAM Lombok Tengah is a local company that provided the drinking water service for all 12 districts in central Lombok. Praya City is the biggest area of service that coverage 71,83\% of costumers of PDAM Lombok Tengah. Therefore this area should be given the most concern in term of services quality. Complains that have been sent by costumers towards PDAM Lombok Tengah is indicating the dissatisfaction in services. PDAM Lombok Tengah must be able to examine the conditions and phenomena in the community related to factors that affect the satisfaction of its customers, and then respond with the implementation of adequate quality management.

According to the research that has been done the highest average score of quality management implementation rate is $75,88 \%$, this score is implied by using and communicating costumers information.

The Satisfaction rate of domestic costumers of PDAM Lombok Tengah in Praya City is shown to be satisfied enough with average rate of $64,167 \%$. This rate is influenced by water quality, water continuity, water pressure, water's meter condition, maintenance, billing and payment system, services cost, and water quality

Keywords: Quality Management, Costumer, Satisfaction rate, Iimplementation. 


\section{PENDAHULUAN}

\section{Latar Belakang}

Kota Praya sebagai salah satu wilayah pelayanan PDAM Lombok Tengah memeberikan andil yang cukup besar dalam memberikan keuntungan bagi PDAM Lombok Tengah. Kondisi ini perlu diimbangi dengan pelayanan yang maksimal dari pihak perusahaan. Terlebih lagi Kota Praya merupakan daerah yang cukup luas.

Adanya keluhan-keluhan para pelanggan terhadap pelayanan yang diberikan oleh PDAM Lombok Tengah indikasi belum optimalnya pelayanan yang diberikan oleh PDAM Lombok Tengah. Keluhankeluhan tersebut umunya bersifat teknis, seperti permasalahan-permasalahan yang menyangkut kualitas, kuantitas, kelancaran, serta tekanan air, termasuk kondisi meter air yang sudah tidak layak pakai, serta pemeliharaan dan perbaikan yang dilakukan petugas terhadap instalasi-instalasi yang ada.

Semakin besarnya tuntutan masyarakat dan tantangan yang dihadapi oleh PDAM Lombok Tengah saat ini, maka PDAM Lombok Tengah perlu memiliki strategi, sasaran utama dan program kerja yang jelas. Untuk mencapai misi utama yang telah ditetapkan, untuk mewujudkan hal tersebut, PDAM Lombok Tengah harus mampu mencermati kondisi dan fenomena-fenomena di masyarakat yang menyangkut faktor-faktor yang mempengaruhi kepuasan pelanggan-pelanggannya, untuk kemudian direspon dengan implememntasi manajemen kualitas yang memadai. Penelitian dilakukan pada Kota Praya yang merupakan wilayah pelayanan PDAM Lombok Tengah dengan prosentase jumlah pelanggan terbesar.

\section{Tujuan Penelitian}

Berdasarkan latar belakang di atas, Tujuan dari penelitian ini untuk :

1. Mengetahui faktor-faktor apa saja yang mempengaruhi tingkat kepuasan terhadap pelayanan PDAM Lombok Tengah di kecamatan Kota Praya

2. Mengetahui tingkat kualitas implementasi PDAM Lombok Tengah di kecamatan Kota Praya.

\section{METODE PENELITIAN}

Penelitian ini merupakan penelitian asosiatif kausal, yaitu penelitian yang bertujuan untuk menganalisis hubungan antara satu variabel dengan variable lainya atau bagaimana suatu variabel mempengaruhi variabel lain ( Umar (2003).

\section{Popuasi dan Sampel}

Populasi pelanggan PDAM di Kota Praya tentu banyak, namun dalam penelitian ini ditentukan sampel sebanyak 120 orang pelanggan eksternal sebagai responden secara random. disamping itu juga digunakan sampel internal yaitu karyawan PDAM .

\section{Jenis dan Sumber Data}

Jenis data yang digunakan dala penelitian ini adalah data kualitatif, yaitu data yang tidak berupa angkaangka dan data kuantitatif yaitu data yang berupa angka-angka. Data dapat bersumber dari data primer yaitu data yang yang bersumber langsung dari, dan dapat bersumber dari data sekunder yaitu data yang diperoleh peneliti dari pihak lain,tidak langsung diperoleh oleh peneliti dari subjek penelitiannya data sekunder biasanya berwujud data dokumentasi atau data laporan yang teleh tersedia seperti literature, artikel, jurnal serta situs di internet yang berkenan dengan penelitian yang dilakukan.

\section{Teknik Pengumpulan Data}

Teknik pengumpulan data yang digunakan dalam penelitian ini adalah sebagai berikut : observasi, wawacara berdasarkan atas daftar pertanyaan yang telah disiapkan terlebih dahulu dan dokumentasi (Sugiyono, 2015) 


\section{Identifikasi dan Klasifikasi Variabel}

Identifikasi variabel terdiri atas : y ( kepuan pelanggan) dan x ( 8 para meter kepuasan pelanggan). Klasifikasi variabel terdiri atas variabel terikat yaitu variabel yang dipengaruhi adalah $Y$ yaitu keputusan pelanggan, sedangkan variabel bebas yaitu variabel yang mempengaruhi yaitu : Kualitas Air (x1), Kuantitas Air (x2), Tekanan Air (x3), Kontinuitas Air (x4), Meter Air (x5), Sistem Penagihan dan Prosedur Pembayaran (6), Perbaikan dan Pemeliharaan (x7), Tarif Pembayaran Air (x8)

\section{Analisis Data}

Dalam menganalisis data penelitian ini digunakan metode diskriptif kuantitatif. Untuk menjawab perumusan masalah sampai sejauh mana tingkat kepuasan pelanggan PDAM Praya terhadap kinerja PDAM, maka digunakan analisis Tingkat Kepentingan dan Kinerja (Martila dan James, 1997 dalam Supranto,1997). Jasa akan menjadi sesuatu yang bermamfaat apabila didasarkan pada kepentingan pelanggan dan kinerjanya bagi perusahaan, artinya PDAM praya seharusnya mencurahkan perhatiannya pada hal-hal yang dianggap penting oleh pelanggan.

Dalam hal ini, digunakan skala likert dengan 5 tingkat yang terdiri dari sangat penting, penting, cukup penting, kurang penting, dan tidak penting. Kelima penilaian tersebut diberikan bobot sebagai berikut :

a. Jawaban yang sangat penting diberi bobot 5

b. Jawaban penting diberi bobot 4

c. Jawaban cukup penting diberi bobot 3

d. Jwaban kurang penting diberi bobot 2

e. Jawaban tidak penting diberi bobobt 1

Untuk kinerja /penampilan diberikan 5 penilaian dengan bobot sebagai berikut:

a. Jawaban sangat baik diberi bobot 5, pelanggan sangat puas

b. Jawaban baik diberi bobot 4 , berarti pelanggan puas

c. Jawaban cukup baik diberi bobot 3, berarti pelanggan kurang puas

d. Jawaban kurang baik diberi bobot 2, berarti pelanggan kurang puas

e. Jawaban tidak baik diberi bobot 1 , berarti pelanggan tidak puas

Skor yang diperoleh dinyatakan dalam persen terhadap skor maksimal. Rentangan skor untuk masingmasing kategori diperoleh sebagai berikut :

Interval kelas : $\frac{100 \%-20 \%}{5}=16 \%$

Berdasarkan atas interval kelas tersebut, maka kategori tingkat kepuasan pelanggan untuk masingmasing item kepuasan adalah sebagai berikut :
a. $<20 \% \quad$ : jelek
b. $20 \%-36 \% \quad$ : sangat tidak puas
c. $>36 \%-52 \%$ : tidak puas
d. $>52 \%-68 \%$ : cukup puas
e. $>68 \%-85 \%$ : puas
f. $>84 \%-100 \% \quad$ : sangat puas

Keenam kategori diatas digunakan juga untuk menentukan tingkat implementasi manajemen kualitas PDAM Praya Lombok-Tengah.

Berdasarkan hasil penilaian tingkat kepentingan dan hasil penilaian kinerja PDAM Praya LombokTengah, maka akan dihasilkan suatu perhitungan mengenai tingkat kesesuaian antara tingkat kepentingan dan tingkat pelaksananya oleh PDAM Praya.

Tingkat kesesuaian adalah hasil perbandingan skor kinerja pelaksaan dengan skor kepentingan. Tingkat kesuaian inilah yang akan menentukan urutan prioritas peningkatan faktor-faktor yang mempengaruhi kepuasan pelanggan.

Dalam penilain ini terdapat 2 buah variabel yang akan diwakilkan oleh huruf $\mathrm{X}$ dan $\mathrm{y}$, dimana $\mathrm{Y}$ merupakan tingkat kinerja perushaan yang memberi kepuasan para pelanggan, sedangkan $\mathrm{Y}$ merupakan tingkat kepentingan pelanggan. Adapun rumus yang digunakan adalah : (supranto,1997)

$$
\mathrm{Tki}=\frac{X i}{Y i} \times 100 \%
$$


Dimana: $\mathrm{Tk}=$ tingkat kesesuaian responden, $\mathrm{XI}=$ skor penilaian kinerja perusahaan, $\mathrm{Yi}=$ skor penilaian kepentingan pelanggan

Selanjutnya sumbu mendatar $\mathrm{X}$ akan diisi oleh skor tingkat pelaksanaan, sedangkan sumbu tegak $\mathrm{Y}$ akan diisi oleh skor tingkat kepentingan. Dalam penyederhanaan rumus, maka untuk setiap faktor yang mempengaruhi kepuasan pelanggan dengan :

$$
\begin{aligned}
& \bar{X}=\frac{\sum X i}{n} \\
& \bar{Y}=\frac{\sum Y i}{n}
\end{aligned}
$$

Dimana:

$\bar{X}=$ skor rata-rata tingkat pelaksanaan

$\bar{Y}=$ skor rata-rata tingkat kepentingan

$\mathrm{n}=$ jumlah responden

Nilai-nilai yang diperoleh kemudian dimasukan kedalam diagram kartesius untuk menentukan tingkat kinerja sekaligus prioritas pekerjaan dari PDAM Praya Lombok Tengah. Nilai K yang digunakan dalam penelitian ini adalah 8 .

\section{HASIL DAN PEMBAHASAN}

\section{Analisis Kinerja PDAM Lombok Tengah}

Penilaian pelaksanaan dan penilaian kepentingan pada faktor-paktor yang mempengaruhi kepuasa PDAM Lombok Tengah. Data tersebut dapat dilihat dari Tabel 1 berikut :

Tabel 1. Perhitungan Rerata Pelaksanaan dan Penilaian Kepentingan pada Factor-faktor yang Mempengaruhi Kepuasan Pelanggan PDAM Lombok Tengah

\begin{tabular}{|r|l|r|r|r|r|}
\hline No & $\begin{array}{l}\text { Faktor yang mempengaruhi } \\
\text { kepuasan pelanggan PDAM } \\
\text { Lombok Tengah }\end{array}$ & $\begin{array}{c}\text { Penilaian } \\
\text { Pelaksanaan }\end{array}$ & $\begin{array}{c}\text { Penilaian } \\
\text { Kepentingan }\end{array}$ & $\mathbf{X}$ & Y \\
\hline 1 & Kualitas air & 436 & 566 & 3,633 & 4,717 \\
\hline 2 & Kuantitas air & 415 & 483 & 3,458 & 4,025 \\
\hline 3 & Tekanan air & 401 & 431 & 3,342 & 3,592 \\
\hline 5 & Kontinuinitas air & 383 & 530 & 3,192 & 4,417 \\
\hline 6 & Kondisi meter air & 372 & 461 & 3,100 & 3,842 \\
\hline & Penagihan dan pembayaran & 448 & 474 & 3,733 & 3,950 \\
\hline 7 & Perbaikan dan pemeliharaan & 347 & 563 & 2,892 & 4,692 \\
\hline 8 & Tariff air & 482 & 365 & 3,567 & 3,042 \\
\hline & Rata - Rata x dan y & & & 3,365 & 4,043 \\
\hline
\end{tabular}

Dari tabel ini kemudian dapat dibuat diagram kartesius yang menunjukan sejauh mana kinerja PDAM Lombok Tengah berdasarkan penilaian para pelanggannya. Diagram kartesius tersebut dapat dilihat pada gambar 1 berikut :

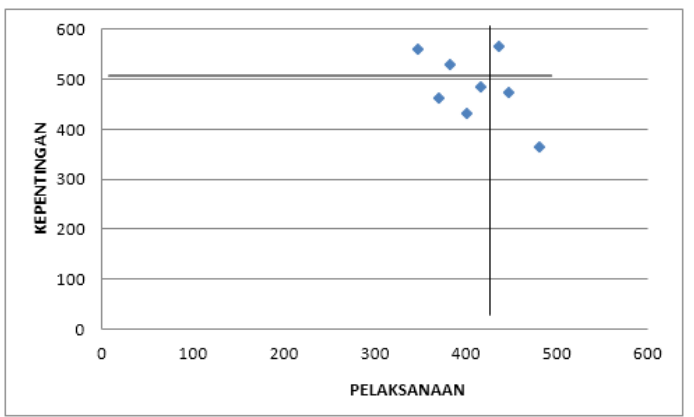

Gambar 1 Grafik Penilaian Kepentingan Dan Pelaksanaan 
Adapun interprestasi dari diagram kartesius tersebut dapat dijelaskan sebagai berikut:

1. Kuadran A

Menunjukan faktorfaktor yang mempengaruhi kepuasan pelanggan PDAM Lombok Tengah berada dalam kuadran ini penanganannya perlu diprioritaskan oleh perusahaan, karena keberadaan factor-faktor inilah yang dinilai sangat penting oleh pelanggan, sedangkan tingkat pelaksanaannya masih belum memuaskan. Faktor-faktor yang termasuk dalam kuadran ini adalah : Kelancaran Air, Perbaikan dan pemeliharaan instalasi air

2. Kuadaran B

Menunjukan factor-faktor yang mempengaruhi kepuasan pelanggan PDAM Lombok Tengah berada dalam kuadran ini perlu dipertahankan. Karena pada umumnya tingkat pelaksanaannya telah sesuai dengan kepentingan dan harapan pelanggan, sehingga dapat memuaskan pelangga. Fakto-faktor yang termasuk dalam kuadran ini adalah : Kualitas Air

3. Kuadran C

Menunjukan factor-faktor yang mempengaruhi kepuasan pelanggan PDAM Lombok Tengah berada dalam kuadran ini masih dianggap kurang penting bagi pelanggan, sedangkam kualitas pelaksanaanya biasa atau cukup saja. Faktor-faktor yang termasuk dalam kuadran ini adalah : Tekanan Air dan Kondisi Meter Air

4. Kuadran D

Menunjukan factor-faktor yang mempengaruhi kepuasan pelanggan PDAM Lombok Tengah berada dalam kuadran ini dinilai berlebihan dalam pelaksanaannya, hal ini terutama disebabkan karena pellanggan menganggap tidak terlalu penting terhadap adanya factor tersebut, akan tetapi pelaksanaanya dilakukan dengan baik sekali oleh perusahaan, sehingga sangat memuaskan, akan tetapi menjadi lebih mahal. Adapun faktor-faktor yang termasuk dalam kuadran D adalah : Kuantitas Air, System penagihan dan prosedur pembayaran dan Tarif Air

\section{Analisa Tingkat Implementasi Manajemen Kualitas}

Dari tabel di atas, diperoleh skor tertinggi untuk tingkat implementasi manajemen kualitas ada pada kategori menggunakan dan mengkomunikasikan informasi pelanggan $(75,88)$. Hal ini menunnjukan komunikasi perusahaan dengan pelanggan, baik itu pelanggan internal maupun eksternal telah berjalan sesuai dengan diharapkan, secara umum tingkat implementasi manajemen kualitas PDAM Lombok Tengah berada dalam kategori baik, yang menunjukan bahwa PDAM Lombok Tengah telah menjalankan konsep-konsep implementasi manajemen kualitas yang berorientasi pada kepuasan pelanggan.

\section{Analisa Tingkat Kepuasan Pelanggan}

Jumlah sampel pelanggan eksternal yang digunakan dalam penelitian ini adalah 120 Sampel, skor maksimum yang dapat diperoleh adalah: Skor maksimum $=5 \times 120=600$

Skor kepuasan pelanggan secara keseluruhan adalah 385 (Lampiran2), sehingga rata-rata skor kepuasan pelanggan PDAM Lombok Tengah wilayah pelayanan Kota Praya adalah :

Skor Tingkat Kepuasan $=\frac{385}{600} \times 100 \%$

$$
=64,167 \%
$$

Skor tingkat kepuasan pelanggan tersebut berada dalam katagori sedang. Hal ini menunjukan bahwa kualitas pelayanan PDAM Lombok Tengah wilayah pelayanan Kota Praya belum bisa memenuhi kebutuhan, keinginan dan harapan pelanggan secara optimal.

\section{Analisa Faktor-Faktor Yang Mempengaruhi Kepuasan Pelanggan PDAM Lombok Tengah Wilayah Pelayanan Kota Praya}

Untuk mencari pengaruh semua factor kepuasan pelanggan secara bersama-sama terhadap kepuasan pelanggan, digunakan regresi linier berganda dengan model :

$\mathrm{Y}=a+b_{1} X_{1}+b_{2} X_{2}+b_{3} X_{3}+b_{4} X_{4}+b_{5} X_{5}+b_{6} X_{6}+b_{7} X_{7}+b_{8} X_{8}$ 
Dengan menggunakan data diatas, dapat dibuat tabel pembantu untuk mencari koefisien regresi dan intersep. Untuk menentukan besarnya koefisien $b_{1}, b_{2}, b_{3}, b_{4}, b_{5}, b_{6}, b_{7}$, dan $b_{8}$, dapat digunakan persamaan simultan sebagai berikut :

$\sum X_{i} Y=b_{1} \sum X_{2}+b_{2} \sum X_{K} \sum X_{2}+\ldots \ldots \ldots \ldots+\mathrm{b}_{\mathrm{k}} \sum X_{1} X_{\mathrm{k}}$

Untuk memudahkan perhitungan, digunakan metode skor deviasi dengan rumus :

$$
S=\sqrt{\frac{\sum f i \times\left(X i-X^{-}\right)^{2}}{N-1}}
$$

Menghitung Mean dapat diperoleh dari rumus sebaga berikut :

$$
X^{-}=\frac{\left(\sum X i\right)}{N}
$$

Nilai Mean untuk Faktor Kualitas Air

$$
X^{-}=\frac{436}{120}=3,6333
$$

Perhitungan skor deviasi :

$$
S=\sqrt{\frac{\sum f i \times \Sigma\left(X i-X^{-}\right)^{2}}{N-1}} S=\sqrt{\frac{120 \times(2702,556)^{2}}{120-1} S} S=0.522
$$

Dengan metode tersebut, kemudian diperoleh hasil sebagai berikut :

Tabel 2. Hasil Peritungan Skor Deviasi

\begin{tabular}{|l|c|c|c|}
\hline & Mean & Std. Deviation & $\mathrm{N}$ \\
\hline Faktor Kepuasan Pelanggan & 3.2083 & 0.70884 & 120 \\
Faktor kualitas air & 3.6333 & 0.62083 & 120 \\
Kuantitas air & 3.4583 & 0.70884 & 120 \\
Faktor tekanan air & 3.3417 & 0.67979 & 120 \\
Kontinuinitas air & 3.1917 & 0.78103 & 120 \\
Kondisi meter air & 3.1 & 0.80335 & 120 \\
Perbaikan dan pemeliharaan & 3.7333 & 0.80683 & 120 \\
Perbaikan dan pemeliharaan & 2.8917 & 0.80748 & 120 \\
Tarif air & 3.5667 & 0.69492 & 120 \\
\hline
\end{tabular}

Hasil dari skor deviasi ini selanjutnya dimasukkan ke dalam persamaan simultan. Kemudian dengan metode eliminasi dan subtitusi, dapat ditentukan besarnya koofisien regresi untuk masing-masing faktor. Untuk mempermudah perhitungan maka dibantu dengan program, diperoleh $b_{1}=0,028, b_{2}=0,118, b_{3}=0,126$, $\mathrm{b}_{4}=0,160, \mathrm{~b}_{5}=-0,184, \mathrm{~b}_{6}=0,092, \mathrm{~b}_{7}=0,063, \mathrm{~b}_{8}=0,051$ (perhitungan dapat dilihat pada lampiran), dengan menggunakan persamaan :

$$
a=\bar{Y}+b_{1} \bar{X}_{1}+b_{2} \bar{X}_{2}+b_{3} \bar{X}_{3}+b_{4} \bar{X}_{4}+b_{5} \bar{X}_{5}+b_{6} \bar{X}_{6}+b_{7} \bar{X}_{7}+b_{8} \bar{X}_{8}
$$

Diperoleh nilai untuk intersep $(a)=0,485$. dari nilai-nilai yang telah diperoleh, didapatkan persamaan regresi linier berganda sebagai berikut :

$Y=0,485+0,028 X_{1}+0,118 X_{2}+0,126 X_{3}+0,160 X_{4}+0,184 X_{5}+0,092 X_{6}+0,063 X_{7}+0,051 X_{8}$ 
Tabel 3. Hasil Analisis Regresi

\begin{tabular}{|c|c|c|c|c|c|}
\hline \multirow[b]{2}{*}{ Model } & \multirow{2}{*}{$\begin{array}{c}\text { Unstandardized } \\
\text { Coefficients } \\
\text { B }\end{array}$} & \multicolumn{2}{|c|}{ Standardized Coefficients } & \multirow[b]{2}{*}{$\mathrm{t}$} & \multirow[b]{2}{*}{ Sig. } \\
\hline & & Std. Error & Beta & & \\
\hline (Constant) & 0.485 & 0.562 & & 0.862 & 0.39 \\
\hline Faktor kualitas air & 0.028 & 0.097 & 0.025 & 0.293 & 0.77 \\
\hline Kuantitas air & 0.118 & 0.169 & 0.118 & 0.701 & 0.485 \\
\hline Faktor tekanan air & 0.126 & 0.121 & 0.121 & 1.043 & 0.299 \\
\hline Kontinuinitas air & 0.16 & 0.089 & 0.177 & 1.813 & 0.073 \\
\hline Kondisi meter air & 0.184 & 0.076 & 0.209 & 2.407 & 0.018 \\
\hline Kondisi meter air & 0.092 & 0.075 & 0.105 & 1.232 & 0.221 \\
\hline $\begin{array}{l}\text { Perbaikan dan } \\
\text { pemeliharaan }\end{array}$ & 0.063 & 0.081 & 0.071 & 0.769 & 0.444 \\
\hline Tarif air & 0.051 & 0.138 & 0.05 & 0.366 & 0.715 \\
\hline
\end{tabular}

Untuk mengetahui signifikan atau tidaknya model diatas dilakukan pengujian hipotesis dengan menggunakan uji Fisher. Dari data didapat,nilai $F_{h}=5,461$. Sedangan nilai $F$ table $(\alpha: 0,05 ;$ df1: $8 ;$ df2: 111) $=1,193$. Nilai $F_{h}$ ini lebih besar dari $F_{t}$ pada taraf nyata $5 \%$ yaitu 1,193 , sehingga model dinyatakan signifikan.

Dari persamaan ini kemudian dapat ditentukan koofisien korelasi $(\mathrm{R})$ dan determinasi $\left(\mathrm{R}^{2}\right)$. Sehingga diperoleh $\mathrm{R}=$ 0,531 hubungan simultan $\mathrm{X} 1, \mathrm{X} 2, \mathrm{X} 3, \mathrm{X} 4, \mathrm{X} 5, \mathrm{X} 6, \mathrm{X} 7$, dan $\mathrm{X} 8$ dengan $\mathrm{Y}$ adalah sebesar 0,531.

Artinya hubungan antara variabel-variabel bebas tesebut dengan $\mathrm{Y}$ berada pada kategori kuat. Sedangkan nilai $\mathrm{R}^{2}=0,282$. Hal ini berarti, dari rata-rata tingkat kepuasan pelanggan PDAM Lombok Tengah wilayah pelayanan Kota Paya 28,00 \% ditentukan oleh faktor kualitas air, kuantitas air, tekanan air, kontinuitas air, kondisi meter air, system penagihan dan pemeliharaan, serta tarif air. Sisanya $72,00 \%$ di tentukan oleh faktor lain.

\section{Pengaruh Faktor Kualitas Air Terhadap Kepuasan Pelanggan}

Untuk mencari pengaruh faktor kualitas air terhadap kepuasan pelanggan digunakan persamaan regresi linier sederhana dengan model :

$\mathrm{Y}=\mathrm{a}+\mathrm{bX}$

Dari data pada lampiran I, dapat dibuat tabel pembantu seperti pada lampiran V, dengan menggunakan rumus :

$$
\mathrm{b}=\frac{n \sum X_{1} Y_{1}-\sum X_{1} \sum Y_{1}}{n \sum X_{1}^{2}-\left(\sum X_{1}\right)^{2}}
$$

diperoleh koefisien regresi

$$
\begin{aligned}
& \mathrm{b}=\frac{(120 \times 1404)-(436 \times 385)}{(120 \times 1630)-\left(436^{2}\right)} \\
& \mathrm{b}=0,1126
\end{aligned}
$$

kemudian nilai dimasukkan ke dalam persamaan :

$$
\begin{aligned}
& a=Y-b X \\
& a=\frac{385}{120}-\frac{436}{120} \\
& a=2,7991
\end{aligned}
$$

setelah itu dicari $\mathrm{R}^{2}$ dimana $\mathrm{R}^{2}=\frac{\left.n \sum X_{1} Y_{1}-\sum X_{1} Y_{1}\right)^{2}}{\left(n \sum X_{1}{ }^{2}-\left(\sum X_{1}\right)^{2}\right)\left(n \sum Y_{1}-1\right.}$

$$
\overline{\left(n \sum X_{1}^{2}-\left(\sum X_{1}\right)^{2}\right)\left(n \sum Y_{1}^{2}-\left(\sum Y_{1}^{2}\right)\right)}
$$

Diperoleh,

$$
\begin{aligned}
& \mathrm{R}^{2}=\frac{(120 \times 1404)-(436 \times 385)^{2}}{(120 \times 1630)-\left(436^{2}\right) \times(120 \times 1293)-(385)^{2}} \\
& =0,010
\end{aligned}
$$

Untuk perhitungan selanjutnya dapat dilihat pada tabel 4, di bawah ini : 
Tabel 4 Hasil perhitungan kepuasan pelanggan

\begin{tabular}{|l|c|c|c|}
\hline \multicolumn{1}{|c|}{ Faktor kepuasan pelanggan } & $\mathbf{b}$ & $\mathbf{a}$ & $\mathbf{R}^{\mathbf{2}}$ \\
\hline Kuantitas air & 0,397 & 1,789 & 0,168 \\
\hline Tekanan air & 0,4266 & 1,844 & 0,153 \\
\hline Kontinuinitas air & 0,3748 & 2,100 & 0,146 \\
\hline Kondisi meter air & 0,319 & 2,114 & 0,159 \\
\hline Penagihan dan pembayaran & 0,1377 & 2,376 & 0,070 \\
\hline Perbaikan dan pemeliharaan & 0,2135 & 2,777 & 0,043 \\
\hline Tarif air & 0,1363 & 2,555 & 0,040 \\
\hline
\end{tabular}

Dapat dilihat bahwa faktor kuantitas air memiliki koefisien determinasi terbesar yaitu $(0,168)$, yang diikuti oleh kondisi meter air $(0,159)$, faktor tekanan air $(0,153)$, kontinuitas $(0,146)$, sistem penagihan dan pembayaran $(0,070)$, perbaikan dan pemeliharaan $(0,043)$, tarif air $(0,040)$, kualitas air $(0,009)$, hal ini berarti bahwa faktor kuantitas air memberikan pengaruh yang paling besar terhadap tingkat kepuasan pelanggan PDAM Lombok Tengah untuk Wilayah Pelayan Kota Praya.

\section{SIMPULAN DAN SARAN}

\section{Simpulan}

Dari hasil penelitian ini dapat disimpulan sebagai berikut:

1. Rata -rata skor penilian tingkat impelmentasi manejemen kuailitas tertinggi adalah $75,88 \%$, skor tersebut berkaitan dengan menggunakan dan mengkomunikasikan imformasi pelanggan

2. Secara umum tingkat kepuasan pelanggan rumah tangga PDAM Kota praya Lombok Tengah berada pada kategori puas. Ini ditunjukan dengan skor tingkat kepuasan rata-rata 64,167\%. dipengaruhi oleh kualitas air, kuantitas air, kondisi meter air, kontinuinitas air, tekanan air, perbaikan dan pemeliharaan, system penagihan dan pembayaran, dan tarif air.

\section{Saran}

1. PDAM Lombok Tengah dalam operasinya perlu meningkatkan kualitas pelayanan agar dapat mencapai kepuasan pelanggan yang maksimal, khususnya bagi pelanggan rumah tangga di wilayah Praya.

2. PDAM Lombok tengah harus lebih bekerja keras untuk mempertahankan serta meningkatkan kualitas implelmentasi manejemen kulitas yang berorientasi pada kepuasan pelanggan.

3. Perlu di lakukan penelitian lanjutan untuk menemukan penyebab penyebab teknis yang mengakibatkan rendahnya kepusan pelanggan pada factor-factor tertentu.

\section{DAFTAR PUSTAKA}

Anonim, 2004, Manajer Jaminan Mutu Pekerjaan Konstrusi Sumber Daya Air (Quallity Asssurance Engineer), Badan Pembinaan Konstruksi Dan Sumber Daya Manusia Dapertemen Pekerjaan Umum Jakarta, Jakarta.

Hidayatullah, 2006, Implementasi Manajemen Kualiatas Dan Faktor-Faktor Yang Mempengaruhi Kepuaan Pelanggan PDAM Mataram, Tugas Akhir, Jurusan Teknik Sipil Fakultas Teknik Unversitas Mataram.

Labaw, P.J., 1992, “Advanced questionnaire design”, Abt Books, Cambridge, Massachusette.

Lorraine, D., 1994, "Surveys and questionnaire design" Paper no. 3 "Research and evalution and community healt series", Flinders prees, South Australia

Ngurah Sunata. I Gede, 2002, tesis: Implementasi Manajemen Kualiatas Dan Faktor-Faktor Yang Mempengaruhi Kepuaan Pelanggan PDAM Bandung, Teknik Sipil Institut Teknologi Sepuluh November Surabaya, Putrawan, I, Made, 1990, Peengujian-Penguijan Hipotesis Dlam PenelitianPenelitian Sosial. Penerbit RINEKA CIPTA, Jakarta.

Sugiyono, 1997, Statistika Untuk Penelitian, Penerbit Alfabeta, Bandung.

Supranto, J., 1992, Pengukuran Tingkat Kepuasan Pelanggan. Penerbit RINEKA CIPTA. Jakarta.

Supranto, J., 1997, Pengukuran Tingkat Kepuasan Pelanggan. Penerbit RINEKA CIPTA. Jakarta.

Sidharta Kamarwan, 1997, Modul: Ilmu Manajemen Konstruksi Untuk Perguruan Tinggi

Yamit, Zulian. 2001, Manajemen Kualitas : Produk dan Jasa. Penerbit EKONISIA.Yogyakarta 